\title{
AN INVASION IN PROGRESS - SINANODONTA WOODIANA (LEA, 1834) (BIVALVIA: UNIONIDAE) IN POLAND
}

\author{
MARIA URBAŃSKA*, WOJCIECH ANDRZEJEWSKI
}

\begin{abstract}
Institute of Zoology, Poznań University of Life Sciences, Wojska Polskiego 28, 60-637 Poznań, Poland (e-mails: urbanska@up.poznan.pl; wojciech.andrzejewski@up.poznan.pl); MU (1) https://orcid.org/0000-0003-1239-8231, WA (i) https://orcid.org/0000-0002-9035-9951 *corresponding author
\end{abstract}

ABSTRACT: We summarise the current knowledge about the Polish population of the Chinese pond mussel. At least 53 locations of the Chinese pond mussel have been confirmed in Poland taking into consideration a literature survey and our own research data comprising new unreported sites. S. woodiana is mostly present in fish ponds $(69.8 \%)$ but for the last few years it has been discovered in lowland rivers, canals and wetlands, too. Considering these population figures the current data about the distribution of $S$. woodiana seem to be underestimated. The spreading rate described in the literature and already available knowledge about $S$. woodiana's biology and its resistance to the environmental conditions indicate that the species should be consider as a really risky invasive species. We suggest that monitoring of $S$. woodiana presence and abundance should be conducted.

KEY WORDS: alien species, Chinese pond mussel, distribution, freshwater mussel

\section{INTRODUCTION}

Invasive alien species have been recognised by "The EU Biodiversity Strategy to 2020" (EUROPEAN COMMISSION 2011) as one of the greatest direct threats to European nature. Alien species predate, hybridise with, parasitise, and out-compete a wide range of native European taxa and, as a result, reduce biodiversity, threaten native species, increase the number of endangered species, and alter ecosystems across the majority of continents (HULME 2007). Human activities in aquaculture and trade promote both the intentional and accidental spread of species across their natural dispersal barriers that has been happening for decades (ANDERSON et al. 2014).

The Chinese pond mussel Sinanodonta woodiana (Lea, 1934) provides a good example of the invasion process. This species has spread on a large scale all over the world. Its natural range lies in Asia and the species appeared in Europe and in America mostly due to the transport of farmed fishes (WATTERS 1997a, b). In Europe it was first discovered in fish farms in Romania in 1979 (SÁRKÁNY-KISS 1986). Chinese pond mussels in Poland probably first appeared in the 1980's in thermal polluted waterbodies and it has already expanded significantly and quickly in recent years. On 9th September 2011 an ordinance was issued by the Ministry of Environment in Poland that concerns the list of plants and animals of alien species which can threaten native species or natural habitats if released to the environment. Among 52 species, the Chinese pond mussel is also named. The $S$. woodiana population has expanded in Poland due to many favourable factors of anthropogenic and environmental origin that have resulted in the growth of local S. woodiana populations and the number of locations where this species has been recorded. Every year new reports of the occurrence of the Chinese pond mussel in Poland are published. The first colonisation traces (empty shells) of S. woodiana in Poland were reported by BöHME (1998). The first stable population in Poland was recorded by 
ZDANOWSKI (1996) who discovered it in reservoirs with elevated water temperature coming from the Konin power plant in western Poland. In 1992 it was discovered that this mussel could get settled even in water basins of natural thermal regime (MIZERA \& URBAŃSKA 2003) and had appeared in fish ponds much earlier (URBAŃSKA et al. 2012).

In addition to the reports about new locations, several types of research have been already conducted to investigate the populations of $S$. woodiana in Poland and their impact on the ecosystem. These include morphological characteristics (AFANASIEV et al. 2001, SOROKA \& ZDANOWSKI 2001, KRASZEWSKI 2006a, b, ANDRZEJEWSKI et al. 2012a, ESZER et al. 2016), reproduction potential (SOROKA 2000, LABECKA 2009, LABECKA \& DOMAGAEA 2018, 2019), habitat preferences (KRASZEWSKI \& ZDANOWSKI 2001a, b, 2007, SPYRA et al. 2012, 2016, ANDRZEJEWSKI et al. 2013), density indices, population distribution (DOMAGAEA et al. 2003, 2007, KRASZEWSKI 2007, URBAŃSKA et al. 2012, 2013, URBAŃSKA \& ANDRZEJEWSKI 2014, SZLAUER-ŁUKASZEWSKA et al. 2017), resistance in relation to different stress pollutants as well as variability at the genetic level (SOROKA \& ZDANOWSKI 2001, SOROKA 2005, 2010, SOROKA et al. 2014).

\section{METHODS}

We take into consideration many sources including the literature survey (scientific papers as well as popular press), internet resources browsing the scientific databases as Google Scholar, Research Gate and Mendeley using key words like "woodiana", "Chinese Pond Mussel", "freshwater mussels", "large mussels", "distribution" (also in Polish spelling) as well as regular, active, annual participation in the "National Carp (Cyprinus carpio) Breeders Conference" through a presentation of the results combined with an appeal for providing information about the observed mussels to the Institute of Zoology, Poznań

\section{RESULTS}

We confirmed the presence of S. woodiana at 53 localities (Fig. 1). The list and basic information of known locations of $S$. woodiana in Poland is shown in Table 1. S. woodiana in Poland is mostly present in fish ponds $(69.8 \%)$, it has also occurred in rivers $(17 \%)$. The other populations were found in canals
Natural enemies - oystercatcher (Haematopus ostralegus), white-tailed eagle (Haliaeetus albicilla), wild boar (Sus scrofa), red fox (Vulpes vulpes), musk rat (Ondatra zibethicus) and otter (Lutra lutra) (ANDRZEJEWSKI et al. 2012b, WOJTON et al. 2012, URBAŃSKA et al. 2013, ROMANOWSKI \& WINCZEK 2017), as well as fouling rates by Dreissena polymorpha on S. woodiana in relation to native species (DZIERŻYŃSKA-BIAŁOŃCZYK et al. 2018, URBAŃSKA et al. 2018) and parasites and symbionts of the Chinese pond mussel (YURYSHYNETS \& KRASUTSKA 2009, CICHY et al. 2016) have been also analysed because it allows determining interactions and conditions that affect the rapidity of its spread. Additionally, the research conducted in Poland in recent years also considered elements accumulation ability of $S$. woodiana (KRÓLAK \& ZDANOWSKI 2001, 2007, KRÓLAK et al. 2007), genotoxic potential (WOŹNICKI et al. 2004) and qualitative and quantitative characterisation of mussel protein preparation (MPP) obtained by electrophoretic separation and differential scanning calorimetry (DSC) (KONIECZNY et al. 2016, StANGIERSKI et al. 2018). In this paper we summarise the data on the distribution of $S$. woodiana in Poland.

University of Life Sciences. A short questionnaire was developed and 250 surveys were distributed personally among fishermen, farm pond owners, fish breeders and anglers and were sent to "Przegląd Rybacki" ("Fisherman Review") subscribers in 2014. 27 questionnaires have been returned. All information was confirmed at the source each time. The research has been performed in natural and artificial reservoirs of flowing or standing water. In some cases, we directly investigated the substrate when water levels were lowered in reservoirs for operational reasons.

(3 sites), power plant cooling systems (2 sites), oxbow and artificial reservoir (one site each). However, it is expected that this number is underestimated because the research about freshwater bivalve molluscs is done by only a few scientific centres in Poland.

\section{DISCUSSION}

In Poland the early stages of $S$. woodiana expansion were found in ponds (URBAŃSKA et al. 2012).

For last few years it has also occurred in rivers including the biggest ones like the Odra and the 


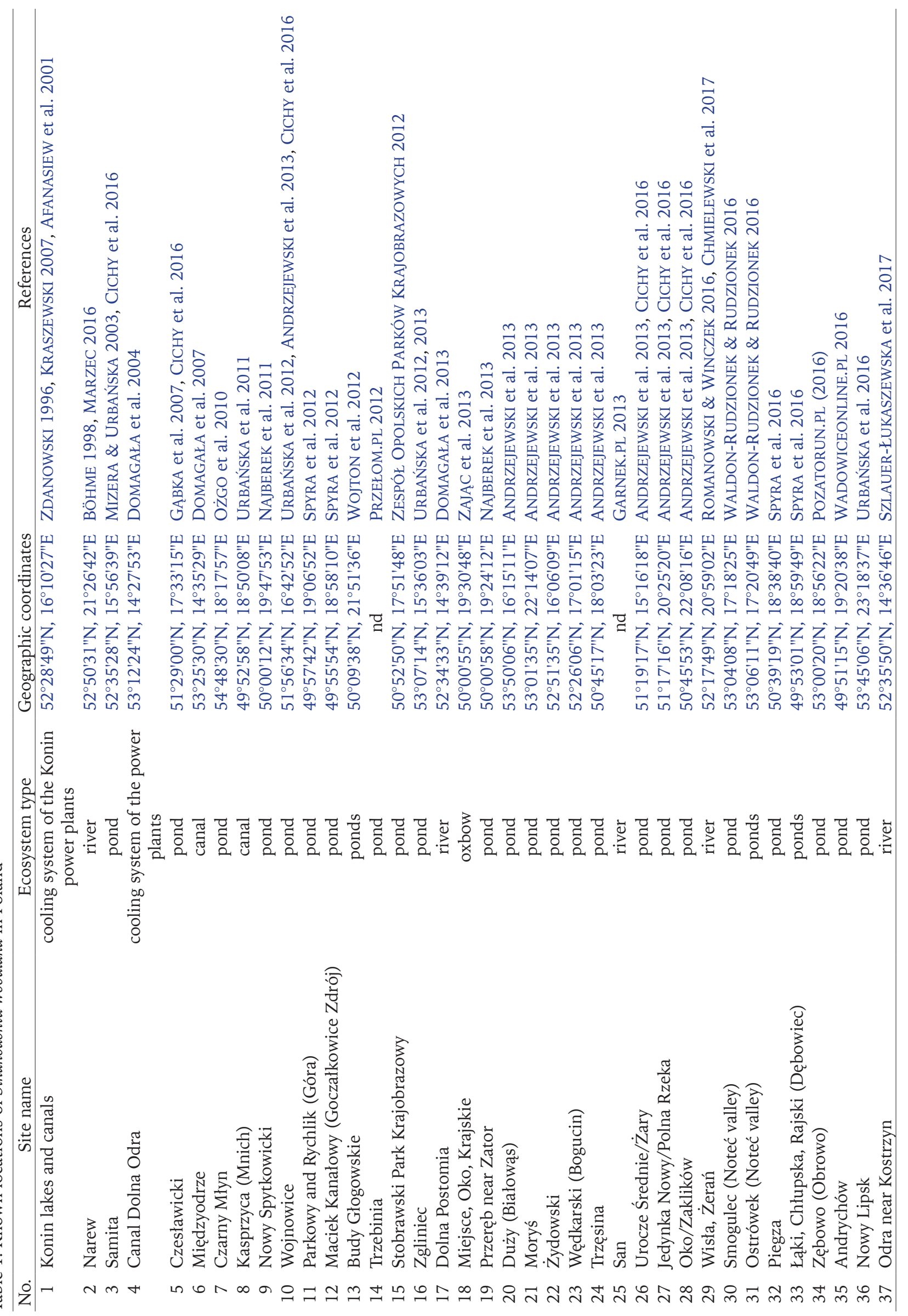




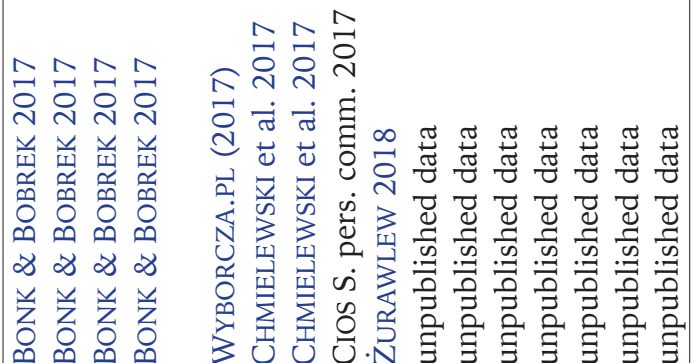

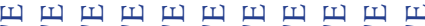

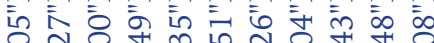
少

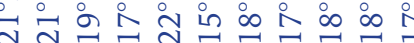

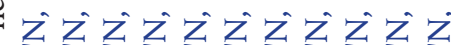
$8=$

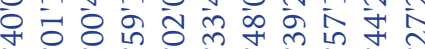

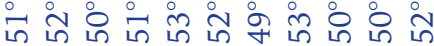

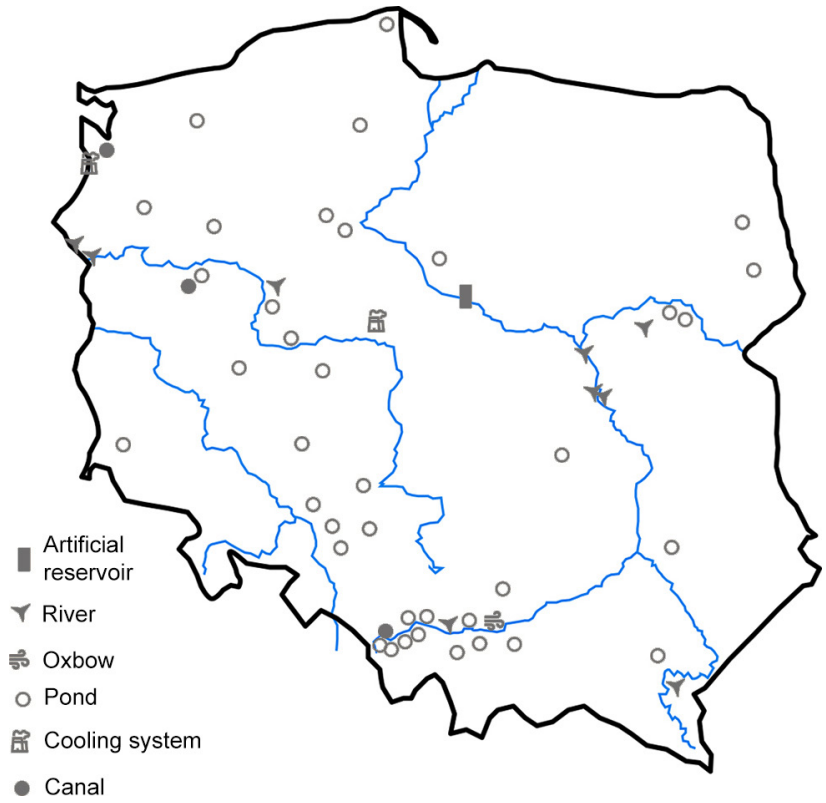

Fig. 1. Confirmed sites of Sinanodonta woodiana occurrence in Poland

Warta. In other countries including Croatia, Italy and the Czech Republic it occurs mainly in lowland rivers (PAUNOVIC et al. 2006, LAJTNER \& CRNČAN 2011, ANDRZEJEWSKI et al. 2013). It means that both ponds and rivers are important water reservoirs for the spread of this species. In recent years more and more locations have been found on the protected areas (e.g. MiZERA \& URBAŃSKA 2003, OŻGO et al. 2010, DOMAGAEA et al. 2013, ZAJAC et al. 2013, URBAŃSKA \& ANDRZEJEWSKI 2014) and also where S. woodiana coexists with native bivalve species (e.g. NAJBEREK et al. 2011, WOJTON et al. 2012, ZAJĄC et al. 2013, URBAŃSKA et al. 2016, SZLAUER-ŁUKASZEWSKA et al. 2017). In the literature, there are reports of noticeable changes in the mussel communities after introduction of the species (URBAŃSKA et al. 2019). FABBRI \& LANDI (1999) reported that $A$. anatina has been replaced almost completely by $S$. woodiana in some channels with soft substrate and high trophic level. BENKO-KIsS et al. (2013), for Lake Balaton, compared data from 2011 to the distribution of unionids measured in 1992/1993. The impact of S. woodiana seemed high and concerned many species. For example $A$. cygnea has been replaced by $S$. woodiana and the species ratio of $A$. anatina was reduced from $17 \%$ to $8 \%$. That is why further increase in population size (and dominance) can be expected in the future. In 2002, NIERO (2003) noted the exclusive presence of $S$. woodiana in a channel with a high trophic level located in Venezia province where a high density of $A$. anatina (up to 10 adult specimens per square meter) was recorded in 1987. Native species reduction could result from competition for the host fish because of greater infestation capacity of $S$. woodiana's glochidia (WATTERS 1997a, b, FABBRI \& LANDI 1999, 
DoudA et al. 2012, 2017a). DoudA et al. (2017b) demonstrated that the metamorphosis success rate of $A$. anatina glochidia was strongly reduced on fish hosts that had been previously exposed to $S$. woodiana. Such cross-resistance may decrease significantly the quality of the host resources available to native mussels and consequently may lead to reduction of species population. The spread of $S$. woodiana may also be the result of its high growth ratio and reproductive potential (POU-ROVIRA et al. 2009, LABECKA \& DOMAGAEA 2018) as well as overall stress-tolerance measured by biochemical markers such as cholinesterase enzyme activity (CORSI et al. 2007). The Chinese pond mussel has also a much higher tolerance of hypoxia than native species (SîRBU et al. 2005). Cyanobacterial blooming has a small influence on this invasive species (DU et al. 2011). Moreover, it has been shown that low temperature of water does not always restrict reproduction (DOMAGAEA et al 2004), as originally believed. Larger shells are often found closer to water sources flowing into lakes because water in such places ensures better oxygenation and carries more biomass that constitutes the food consumed by bivalves (URBAŃSKA et al. 2012, ANDRZEJEWSKI et al. 2013). Finally, there are human actions that contribute to spreading of the mussels. It results from transport of farmed fishes (which can be infected by parasitic $S$. woodiana larvae) and even a commercial trade of specimens that are used in garden ponds to filter water. For example the idea to use mussels as the element of garden ponds cleaning systems were promoted in popular TV program in Poland (TVN 2018) (where S. woodiana was wrongly named $A$. anatina), and these mussels were often sold on the local markets and even abroad, e.g. 20,000 individuals from Konin Canals were ordered by garden shops in Germany few years ago (MOKRZYCKI H. pers. comm. 2016). S. woodiana as a large mussel with amber-brown colour of the shell seems more attractive than native species for many people. Moreover, it is often confused with native species so people do not consider it problematic.

As mentioned above the $S$. woodiana population has expanded in Poland recently because there are many anthropogenic factors supporting its current spread. Fish farming has become more extensive, rendering it more likely to introduce this species to other places. Analysis of the invasion history and genetic structure of $S$. woodiana in Europe (KONEČNÝ et al. 2018) suggests that the process of adaptation was initiated by repeated translocations across Europe. Cold-tolerant S. woodiana populations in Europe do not originate from a new invasion source but likely evolved in Europe and started occupying mussel-suitable habitats and threaten native species of mussels (KONEČNÝ et al. 2018).

Given the current status of S. woodiana in Poland it is recommended to collect data on new sites as well as to monitor already known mussel communities to estimate the spreading rate, the species' biology as well as habitat characteristics determining its occurrence and reproduction. Such detailed data may allow predicting the consequences of its presence and finding methods limit its further invasion (FERREIRA-RODRíGUEZ et al. 2019). It is especially important to know how to protect native mussel species from S. woodiana negative impacts.

\section{REFERENCES}

AFANASIEV S. A., ZDANOWSKI B., KRASZEWSKI A. 2001. Growth and population structure of the mussel Anodonta woodiana (Lea, 1834) (Bivalvia, Unionidae) in the heated Konin lakes system. Archives of Polish Fisheries 9: 123-131.

Anderson L. G., White P. C. L., Stebbing P. D., STENTIFORD G. D., DUNN A. M. 2014. Biosecurity and vector behaviour: Evaluating the potential threat posed by anglers and canoeists as pathways for the spread of invasive non-native species and pathogens. PLoS ONE 9: e92788. https://doi.org/10.1371/journal. pone.0092788

ANDrZeJeWsKi W., PELCZYK M., URbańsKa M., Gierszal H. 2012a. Sclerochronology in determining the age of Sinanodonta woodiana. In: POKRYSZKO B. M. (ed.). The 27th Polish Malacological Seminar (seminar report and abstracts). Folia Malacologica 20: 43-71 (p. 46). https://doi.org/10.2478/v10125-012-0001-7
ANDRZEJEWSKI W., URBAŃSKA M., GIERSZAL H. 2012b. Szczeżuja chińska w zbiornikach sąsiadujących z lasami. Studia i Materiały CPEL 33: 345-350.

ANDRZEJEWSKI W., URBAŃSKA M., MAZURKIEWICZ J., Gierszal H., GolsKi J. 2013. The current invasion status of Sinanodonta woodiana (Lea, 1934) in Poland - study of habitat parameters. Oceanological and Hydrobiological Studies 42: 173-180. https://doi. org/10.2478/s13545-013-0071-1

Benkő-Kiss A., Ferincz Á., Kováts N., PAulovits G. 2013. Spread and distribution pattern of Sinanodonta woodiana in Lake Balaton. Knowledge \& Management of Aquatic Ecosystems 408: 09 (p1-p7). https://doi. org $/ 10.1051 / \mathrm{kmae} / 2013043$

BÖHME M. 1998. Ein neuer Fundort der Chinesischen Teichmuschel (Sinanodonta woodiana) in Mitteleuropa. Heldia 2: 166.

BONK M., BOBREK R. 2017. Kolejne stwierdzenia szczeżui chińskiej w dorzeczu Wisły. Wszechświat 118: 221-223. 
CHMIELEWSKI S., ROMANOWSKI J., STRUŻYŃSKI W. WINCZEK M. 2017. Stanowiska szczeżui chińskiej Sinanodonta woodiana (Lea, 1834) (Eulamellibranchia: Unionidae) w środkowej Wiśle. Kulon 22: 149-155.

CiCHY A., URbAŃSKA M., MARSZEWSKA A., ANDRZEJEWSKI W., ŻBIKOWSKA E. 2016. The invasive Chinese pond mussel Sinanodonta woodiana (Lea, 1834) as a host for native symbionts in European waters. Journal of Limnology 75: 288-296. https://doi.org/10.4081/jlimnol.2016.1334

Corsi I., Pastore A. M., Lodde A., Palmerini E., CASTAGNOLO L., FoCARDI S. 2007. Potential role of cholinesterases in the invasive capacity of the freshwater bivalve, Anodonta woodiana (Bivalvia: Unionacea): A comparative study with the indigenous species of the genus, Anodonta sp. Comparative Biochemistry and Physiology Part C: Toxicology and Pharmacology 145: 413-419. https://doi.org/10.1016/j.cbpc.2007.01.011

Domagata J., CieŚliK Ł., PILECKA-RAPACZ M. 2013. Chinese clam (Sinanodonta woodiana) in the National Park Ujście Warty. In: PoKRYSZKo B. M. (ed.). The 29th Polish Malacological Seminar (seminar report and abstracts). Folia Malacologica 21: 183-203 (p. 188). https://doi.org/10.12657/folmal.021.022

Domagata J., LABECKA A. M., MigdalsKa B., PileCKARAPACZ M. 2007. Colonisation of the channels of Międzyodrze (north-western Poland) by Sinanodonta woodiana (Lea, 1834) (Bivalvia: Unionidae). Polish Journal of Natural Sciences 22: 679-690.

DOMAGAŁA J., LABECKA A. M., SOROKA M., ZDANOWSKI B., SKRZYPKOWSKA A. 2004. Anodonta woodiana (Lea, 1834) from the heated Konin lakes matured in aquaria. In: POKRYSZKO B. M. (ed.). The 20th Polish Malacological Seminar (seminar report and abstracts). Folia Malacologica 12: 83-106 (pp. 86-87). https://doi. org/10.12657/folmal.012.006

Domagata J., MigdalsKA B., LABECKA A., PILECKARAPACZ M. 2003. Anodonta woodiana (Lea, 1834) na Pomorzu Zachodnim. Acta Biologica Uniwersytetu Szczecińskiego 10: 199-202.

DoudA K., VRTíleK M., SLAVÍK O., Reichard M. 2012. The role of host in explaining the invasion success of the freshwater mussel Anodonta woodiana in Europe. Biological Invasions 14: 127-137. https://doi. org/10.1007/s10530-011-9989-7

DOUDA K., LIU H-Z., YU D., ROUCHET R., LIU F., TANG Q-Y., Methling C., SMith C., Reichard M. 2017a. The role of local adaptation in shaping fish-mussel coevolution. Freshwater Biology 62: 1858-1868. https://doi. org/10.1111/fwb.13026

DOUDA K., VELÍŠEK J., KOLÁŘOVÁ J., RYLKOVÁ K., SLAVÍK O., HORKÝ P., LANGROVÁ I. 2017b. Direct impact of invasive bivalve (Sinanodonta woodiana) parasitism on freshwater fish physiology: evidence and implications. Biological Invasions 19: 989-999. https://doi. org/10.1007/s10530-016-1319-7

DU L., LI Y., CHEN X., YANG J. 2011. Effect of eutrophication on molluscan community composition in the Lake Dianchi (China, Yunnan). Limnologica 41: 213-219. https://doi.org/10.1016/j.limno.2010.09.006
DZIERŻYŃSKA-BIAŁOŃCZYK A., MAĆKIEWICZ T., GAJEWSKA J., KOBAK J. 2018. Mechanisms and impact of differential fouling of the zebra mussel Dreissena polymorpha on different unionid bivalves. Freshwater Biology 63: 687-699. https://doi.org/10.1111/fwb.13107

ESZER O., URBAŃSKA M., ANDRZEJEWSKI W., GIERSZAL H. 2016. Is sclerochronology a waste of time? In: POKRYSZKO B. M. (ed.). The 31st Polish Malacological Seminar (seminar report and abstracts). Folia Malacologica 24: 31-51 (p. 36). https://doi. org/10.12657/folmal.024.003

EUROPEAN COMMISSION 2011. Our life insurance, our natural capital: an EU biodiversity strategy to 2020 (COM/2011/244 final).

FABBRI R., LANDI L. 1999. Nuove segnalazioni di molluschi, crostacei e pesci esotici in Emilia Romagna e prima segnalazioni di Corbicula fluminea (O. F. Müller, 1774) in Italia (Mollusca Bivalvia, Crustacea Decapoda, Osteichthyes Cypriniform). Quaderno di Studi e Notizie di Storia Naturale della Romagna 19: 9-20.

FERREIRA-RODRÍGUEZ N., AKIYAMA Y. B., AKSENOVA O. V., Araujo R., Barnhart M. C., Bespalaya Y. V., Bogan A. E., Bolotov I. N., Budha P. B., Clavijo C., CleARWATER S. J., DARRIGRAN G., DO V. T., DOUDA K., Froufe E., GumPINGER C., HENRIKSON L., HUMPHREY C. L., JOHNSON N. A., KLISHKO O., KLUNZINGE M. W., KOVITVADHI S., KOVITVADHI U., LAJTNER J., LOPESLima M., MOORKens E. A., NAGaYAMA S., NAGEL K.O., NAKANO M., NEGISHI J. N., ONDINA P., OUlASVIRTA P., Prié V., Riccardi N., Rudzíte M., SHELdON F., SOUSA R., STRAYER D. L., TAKEUCHI M., TASKINEN J., TEIXEIRA A., TIEMANN J. S., URBAŃSKA M., VARANDAS S., VINARSKI M. V., WICKLOW B. J., ZAJĄC T., VAUGHAN C. C. 2019. Research priorities for freshwater mussel conservation assessment. Biological Conservation 231: 77-87. https://doi.org/10.1016/j.biocon.2019.01.002

GARNEK.PL 2013. Muszla. Available online at www.garnek. $\mathrm{pl} /$ dana02/26119051/muszla (accessed 5th January 2019).

GĄBKA M., DOlatA P. T., ANTONOWiCZ R. 2007. New localities of the Chinese clam Sinanodonta woodiana (Lea, 1834) (Bivalvia, Unionidae) in the Barycz River Valley (Wielkopolska Great Poland Region). Folia Malacologica 15: 71-74. https://doi.org/10.12657/folmal.015.008

HulmE P. E. 2007. Biological invasions in Europe: drivers, pressures, states, impacts and responses. In: HESTER R., HARRISON R. M. (eds). Biodiversity under Threat. Cambridge University Press, Cambridge, pp. 56-80.

KONEČNÝ A., POPA O. P., BARTÁKOVÁ V., DOUDA K., BRYJA J., SMith C., POPA L. O., ReICHARD M. 2018. Modelling the invasion history of Sinanodonta woodiana in Europe: Tracking the routes of a sedentary aquatic invader with mobile parasitic larvae. Evolutionary Applications 11: 1975-1989. https://doi.org/10.1111/eva.12700

KONIECZNY P., TOMASZEWSKA-GRAS J., ANDRZEJEWSKI W., MiKoŁajCZaK B., UrbańsKa M., MAZURKIEWICZ J., STANGIERSKI J. 2016. DSC and electrophoretic studies on protein denaturation of Anodonta woodiana (Lea, 1834). Journal of Thermal Analysis and Calorimetry 126: 69-75. https://doi.org/10.1007/s10973-0165707-0 
KRASZEWSKI A. 2006a. Morphological variation in the Chinese clam Sinanodonta woodiana (Lea, 1834) in the heterogeneous conditions of the Konin heated lake system in central Poland. Folia Malacologica 14: 11-23. https://doi.org/10.12657/folmal.014.002

KRASZEWSKI A. 2006b. Conditions for the growth and development of the population of the new clam species to Poland Sinanodonta woodiana (Lea, 1834) in antropogenicaly transformed ecosystem. Polish Journal of Natural Sciences 20: 325-343.

KRASZEWSKI A. 2007. The continuing expansion of Sinanodonta woodiana in Poland and Europe. Folia Malacologica 15: 65-69. https://doi.org/10.12657/folmal.015.007

KRASZEWSKI A., ZDANOWSKI B. 2001a. The distribution and abundance of the Chinese mussel Anodonta woodiana (Lea, 1834) in the heated Konin lakes. Archives of Polish Fisheries 9: 253-265.

KRASZEWSKI A., ZDANOWSKI B. 2001b. Chińskie małże Anodonta woodiana (Lea, 1834) w systemie podgrzanych jezior Konińskich. Komunikaty Rybackie 5: 20-21.

KRASZEWSKI A., ZDANOWSKI B. 2007. Sinanodonta woodiana (Lea, 1834) (Mollusca) - a new mussel species in Poland: occurrence and habitat preferences in a heated lake system. Polish Journal of Ecology 55: 337-356.

KRÓlAK E., PYKA J. P., ZDANOWSKI B. 2007. Heavy metals in the Konin Lake System. Archives of Polish Fisheries 15: 273-286.

KRÓLAK E., ZDANOWSKI B. 2001. The bioaccumulation of heavy metals by the mussels Anodonta woodiana (Lea, 1834) and Dreissena polymorpha (Pall.) in the heated Konin lakes. Archives of Polish Fisheries 9: 229-237.

KRÓlAK E., ZDANOWSKI B. 2007. Phosphorus and calcium in the mussels Sinanodonta woodiana (Lea) and Dreissena polymorpha (Pall.) in the Konin Lake System. Archives of Polish Fisheries 15: 247-446.

LABECKA A. M. 2009. Cykl płciowy zawleczonych gatunków małży Sinanodonta woodiana (Lea, 1834), Corbicula fluminea (O. F. Müller, 1774) oraz Corbicula fluminalis (O. F. Müller, 1774) (Mollusca: Bivalvia) z kanału zrzutowego wód pochłodniczych Elektrowni Dolna Odra. PhD Thesis, University of Szczecin, Szczecin.

LABECKA A. M., DOMAGAŁA J. 2018. Continuous reproduction of Sinanodonta woodiana (Lea, 1824) females: an invasive mussel species in a female-biased population. Hydrobiologia 810: 57-76. https://doi.org/10.1007/ s10750-016-2835-2

LABECKA A. M., Domagata J. 2019. Two pathways for spermatogenesis in Sinanodonta woodiana (Lea, 1834) (Bivalvia: Unionidae). Journal of Molluscan Studies (eyz: 1-11) (in print). https://doi.org/10.1093/mollus/ eyz012

LAJTNER J., CRNČAN P. 2011. Distribution of the invasive bivalve Sinanodonta woodiana (Lea, 1834) in Croatia. Aquatic Invasions 6 (Supplement 1): S119-S124. https://doi.org/10.3391/ai.2011.6.S1.027

MARZEC M. 2016. Nowe stwierdzenie szczeżui chińskiej Sinanodonta woodiana w Narwi. Chrońmy Przyrodę Ojczystą 72: 228-232.
MiZERA T., URBAŃSKA M. 2003. A record of Anodonta woodiana (Lea) from the Sierakowski Landscape Park. In: POKRYSZKO B. M. (ed.). Conference report: the 19th Polish Malacological Seminar (seminar report and abstracts). Folia Malacologica 11: 103-114 (p. 110). https://doi.org/10.12657/folmal.011.011

NajBerek K., Solarz W., Król W., PęPKowsKa-Król A., STRZAŁKA M. 2013. New location of the Chinese mussel Sinanodonta woodiana in Przeręb ponds near the town of Zator. Chrońmy Przyrodę Ojczystą 68: 155-158.

NajBereK K., StrzatKa M., Solarz W. 2011. Alien Sinanodonta woodiana (Lea, 1834) and protected Anodonta cygnea (Lineaeus, 1758) (Bivalvia: Unionidae) in the Spytkowice pond complex. Folia Malacologica 19: 31-33. https://doi.org/10.2478/v10125-011-0011-x

NIERO I. 2003. Sulla presenza in Veneto e centro Italia di Anodonta woodiana woodiana (Lea, 1834) (Mollusca, Bivalvia). Bollettino del Museo Civico di Storia Naturale di Venezia 54: 29-33.

OżGo M., BogUCKI Z., JANULIS E. 2010. Sinanodonta woodiana in a natural water body in the buffer zone of the Słowiński National Park. In: POKRYSZKO B. M. (ed.). The 26th Polish Malacological Seminar (seminar report and abstracts). Folia Malacologica 18: 123-145 (p. 139). https://doi.org/10.2478/v10125-010-0013-0

Paunovic M., CsÁnYi B., Simic V., STOJanovic B., CAKIC P. 2006. Distribution of Anodonta (Sinanodonta) woodiana (Lea, 1834) in inland waters of Serbia. Aquatic Invasions 1: 154-160.

Pou-Rovira Q., Araujo R., Boix D., Clavero M., Feo C., OrdeiX M., ZAMORA L. 2009. Presence of the alien Chinese pond mussel Anodonta woodiana (Lea, 1834) (Bivalvia, Unionidae) in the Iberian Peninsula. Graellsia 65: 67-70.

POZATORUN.PL 2016. Uśmiech wielkiej szczeżui. Available online at www.pozatorun.pl/archiwa/usmiech-wielkiej-szczezui (accessed 5th January 2019).

PRZEŁOM.PL (PORTAL ZIEMI CHRZANOWSKIEJ) 2012. Trzebinia. Znalazł w stawie szczeżuję. Available online at https://przelom.pl/2458-trzebinia-znalazl-w-stawie-szczezuje.html (accessed 3rd January 2019).

ROMANOWSKI J., WINCZEK M. 2017. The musk rat Ondatra zibethicus discovers the Chinese clam Sinanodonta woodiana in the Vistula in Warsaw. In: POKRYSZKO B. M. (ed.). The 32nd Polish Malacological Seminar (seminar report and abstracts). Folia Malacologica 25: 37-67 (p. 61). https://doi.org/10.12657/folmal.025.002

SÁRKÁNY-KISS A. 1986. Anodonta woodiana (Lea, 1834) a new species in Romania (Bivalvia, Unionacea). Travaux du Muséum National d'Histoire Naturelle "Grigore Antipa" 28: 15-17.

SÎRBU I., SÁRKÁNY-KISS A., SîRBU M., BENEDYK A. M. 2005. The Unionidae from Transylvania and neighboring regions (Romania). Heldia 6(3/4): 183-192.

SOROKA M. 2000. Age structure and sex ratio of Anodonta woodiana (Lea, 1834) (Bivalvia: Unionidae) from Konin reservoirs (C Poland). Folia Malacologica 8: 239-244. https://doi.org/10.12657/folmal.008.019

SOROKA M. 2005. Genetic variability among freshwater mussel Anodonta woodiana (Lea, 1834) (Bivalvia: 
Unionidae) populations recently introduced in Poland. Zoological Science 22: 1137-1144. https://doi. org/10.2108/zsj.22.1137

SOROKA M. 2010. Characteristics of mitochondrial DNA of unionid bivalves (Mollusca: Bivalvia: Unionidae). II. Comparison of complete sequences of maternally inherited mitochondrial genomes of Sinanodonta woodiana and Unio pictorum. Folia Malacologica 18: 189-209. https://doi.org/10.2478/v10125-010-0016-X

SOROKA M., URBAŃSKA M., ANDRZEJEWSKI W. 2014. Chinese pond mussel Sinanodonta woodiana (Lea, 1834) (Bivalvia): origin of the Polish population and GenBank data. Journal of Limnology 73: 454-458. https://doi. org/10.4081/jlimnol.2014.938

SOROKA M., ZDANOWSKI B. 2001. Morphological and genetic variability of the population of Anodonta woodiana (Lea, 1834) occurring in the heated Konin lakes system. Archives of Polish Fisheries 9: 239-252.

Spyra A., JęDrASZEWSKA N., STRZELEC M., KRODKIEWSKA M. 2016. Further expansion of the invasive mussel Sinanodonta woodiana (Lea, 1834) in Poland - establishment of a new locality and population features. Knowledge \& Management of Aquatic Ecosystems 417: 41 (1-11). https://doi.org/10.1051/kmae/2016028

SPyRA A., STRZELEC M., LEWIN I., KRODKIEWSKA M., MiCHALIK-KUCHARZ A., GARA M. 2012. Characteristics of Sinanodonta woodiana (Lea, 1834) populations in fish ponds (Upper Silesia, Southern Poland) in relation to environmental factors. International Review of Hydrobiology 97: 12-25. https://doi.org/10.1002/ iroh.201111425

STANGIERSKI S., ANDRZEJEWSKI W., TOMASZEWSKA-GRAS J., GrZEŚ B., KONIECZNY P., URBAŃSKA M. 2018. Effect of washing on the quality of surimi-like preparation obtained from soft tissue of freshwater mussel Sinanodonta woodiana (Lea, 1834). Journal of Aquatic Food Product Technology 27: 961-974. https://doi.org/10.1080/104 98850.2018.1518360

SZLAUER-ŁUKASZEWSKA A., ANDRZEJEWSKI W., GIERSZAL H., URBAŃSKA M. 2017. Co-occurrence of Sinanodonta woodiana with native Unionidae in the lower Oder. Oceanological and Hydrobiological Studies 46: 244248. https://doi.org/10.1515/ohs-2017-0025

TVN 2018. Maja w Ogrodzie. Ogródek jak pudełeczko (odc. 677/ HGTV odc. 15 seria 2018). Available online at http://majawogrodzie.tvn.pl/407, Ogrodek-jak-pudeleczko-odc-677-HGTV-odc-15-seria-2018,odcinek. html (accessed 3rd January 2019)

URBAŃSKA M., ANDRZEJEWSKI W. 2014. Current status of Sinadonta woodiana (Lea 1834) in Poland. In: BISCARINI CH., Pierleoni A., NASEll-Flores L. (eds). Lakes: the mirrors of the Earth. Balancing ecosystem integrity and human wellbeing. Special Session - Alien species: an increasing threat to freshwater ecosystems? Proceedings of the 15th World Lake Conference, 1-5 Sept. Perugia, Italy. Vol. 2. Science4 Press, Perugia: 87-90.

URbAŃSKA M., ANDRZEJEWSKI W., BiAŁOWĄS H. 2011. Małż gigant. Przegląd Rybacki 3: 24.

URBAŃSKA M., ANDRZEJEWSKI W., GIERSZAL H., GOLSKI J. 2018. Are there any differences in the fouling of the native and invasive Unionidae by Dreissena polymorpha? Inland Waters 9: 73-77. https://doi.org/10.1080/2044 2041.2018.1502985

URBAŃSKA M., ANDRZEJEWSKI W., ŁAKOMY A., GIERSZAL H. 2013. Predation on alien species: a case of oystercatcher (Haematopus ostralegus) foraging on Sinanodonta woodiana - an alien pond mussel. Polish Journal of Ecology 61: 175-177.

URBAŃSKA M., ŁAKOMY A., ANDRZEJEWSKI W., MAZURKIEWICZ J. 2012. The story of one clam. Probably the oldest location of the Chinese pond mussel Sinanodonta woodiana (Lea, 1834) (Bivalvia, Unionidae) in Poland. Oceanological and Hydrobiological Studies 41: 41-45. https://doi.org/10.2478/s13545-012-00053

URbAŃSKA M., OŻGo M., ANDRZEJEWSKI W., GIERSZAL H. 2016. Stranger among indigenous - is coexistence of Sinanodonta woodiana with native Unionidae possible? International Congress of Unitas Malacologica, World Congress of Malacology, 18-24 July 2016, Penang, Malaysia.

URBAŃSKA M., KIRSCHENSTEIN M., OBOLEWSKI K., OŻGO M. 2019. Silent invasion: Sinanodonta woodiana successfully reproduces and possibly endangers native mussels in the north of its invasive range in Europe. International Review of Hydrobiology 2019: (1-10). https://doi.org/10.1002/iroh.201801971

WADOWICEONLINE.PL (TWOJE MIASTO W SIECI) 2016. Karpie, amury i ... małże. Takie cuda w andrychowskim stawie. Available online at wadowiceonline.pl/rozmaitosci/8653-karpie-amury-i-malze-takie-cuda-w-andrychowskim-stawie (accessed 3rd January 2019).

WALDON-RUDZIONEK B., RUDZIONEK B. 2016. Nowe stanowisko szczeżui chińskiej Sinonodonta woodiana (Lea, 1834) w dolinie Noteci (Wielkopolska). Przegląd Przyrodniczy 27: 105-106.

WATTERS T. 1997a. A synthesis and review of the expanding range of the Asian freshwater mussel Anodonta woodiana (Lea, 1834) (Bivalvia: Unionidae). Veliger 40: 152-156.

WATtERS G. T. 1997b. Individual-based models of mussel-fish interactions: a cautionary study. In: CUMMINS K. S., BUChANAN A. C., MAYER C. A., NAIMO T. J. (eds). Proceedings of a UMRCC symposium. Conservation and management of freshwater mussels. II: Initiatives for the Future. St. Louis, Missouri, USA, October 16-18, 1995. Upper Mississippi River Conservation Committee, Rock Island, USA: 45-62.

Wojton A., KasprzyK I., KościóŁeK P., Pilch K. 2012. The occurrence of the protected swan mussel Anodonta cygnea (Linnaeus, 1758) and the invasive alien Chinese mussel Sinanodonta woodiana (Lea, 1834) in the fish ponds in the Wisłok River Basin (SE Poland). Folia Malacologica 20: 135-138. https://doi.org/10.2478/ v10125-012-0018-y

WOŹNICKI P., LEWANDOWSKA R., BRZUZAN P., ZIOMEK E., BARDEGA R. 2004. The level of DNA damage and the frequency of micronuclei in haemolymph of freshwater mussels (Anadonta woodiana) exposed to benzo[a]pyrene. Acta Toxicologica 12: 41-45. 
WyBORCZA.PL 2017. Szczeżuja wielka. Ale wielka! Wakacyjne znalezisko z Podlasia. Available online at wyborcza.pl/7,75400,22146045,szczezuja-wielka-ale-wielka-wakacyjne-znalezisko-z-podlasia.html (accessed 4th January 2019).

YURYSHYNETS V., KRASUTSKA N. 2009. Records of the parasitic worm Aspidogaster conchicola (Baer 1827) in the Chinese pond mussel Sinanodonta woodiana (Lea 1834), Aquatic Invasions 4: 491-494.

ZAJĄC T., POCIECHA A., WILK-WOŹNIAK E., ZAJĄC K., BIELAŃSKI W., CISZEWSKI W., FlOREK J., GOŁĄB M., GUZIK M., LIPIŃSKA A., MYSZKA R., NAJBEREK K., PotoczeK M., Walusiak E., SZCZĘSNY B. 2013. Analiza stanu starorzecza na przykładzie kompleksu starorzeczy „Wiśliska” - obszar Natura 2000 PLH 120084. Chrońmy Przyrodę Ojczystą 68: 116-133.
ZDANOWSKI B. 1996. Nieznana szczeżuja (Anodonta sp.) w podgrzanych jeziorach konińskich. XII Krajowe Seminarium Malakologiczne, Łódź, 25-27.04.1996, Abstracts: 43.

Zespół OpOlsKich PARKóW KRAJOBRAZOWYCH 2012. Nowy obcy gatunek stwierdzony na terenie SPK. Available online at www.zopk.pl/pl/stobrawski-pk/aktualnosci/item/258-nowy-obcy-gatunek-stwierdzonyna-terenie-spk (accessed 3rd January 2019).

ŻURAWLEW P. 2018. Nowe stanowisko szczeżui chińskiej Sinanodonta woodiana (Lea, 1834) (Bivalvia: Unionidae) w Wielkopolsce. Przegląd Przyrodniczy 29: 115-118.

Received: February 3rd, 2019

Revised: July 27th, 2019

Accepted: August 7th, 2019

Published on-line: October 30th, 2019 